Collecting the Show on the Road: Spotlight on Anna Mieszkowska and the Polish Cabaret Archive

Author(s): Beth Holmgren

Source: The Polish Review, Vol. 59, No. 4 (2014), pp. 3-20

Published by: University of Illinois Press on behalf of the Polish Institute of Arts \& Sciences of America

Stable URL: http://www.jstor.org/stable/10.5406/polishreview.59.4.0003

Accessed: 28-08-2015 06:13 UTC

Your use of the JSTOR archive indicates your acceptance of the Terms \& Conditions of Use, available at http://www.jstor.org/page/ info/about/policies/terms.jsp

JSTOR is a not-for-profit service that helps scholars, researchers, and students discover, use, and build upon a wide range of content in a trusted digital archive. We use information technology and tools to increase productivity and facilitate new forms of scholarship. For more information about JSTOR, please contact support@jstor.org. 
The Polish Review, Vol. 59, No. 4, 2014

(c) The Board of Trustees of the University of Illinois

\author{
Beth Holmgren
}

\title{
Collecting The Show on the Road: Spotlight on AnNa MieszKowsKa and the Polish Cabaret ArChive
}

The article introduces and then gives a transcription of an interview with Anna Mieszkowska, an archivist at the Polish Academy of Sciences who specializes in collecting materials relating to Polish cabaret of the interwar and wartime era. The introduction justifies the historical and cultural importance of her work and outlines the materials housed in this unique archive and how they are organized. In the interview, Mieszkowska chronicles her efforts to document prewar and émigré cabaret. She began her research tentatively in the 1980s, despite the inattention given by Polish theater studies of that time to cabaret and official disapproval. Mieszkowska's research and related travels became easier after the fall of communism, but more urgent due to the advancing age of surviving performers. The interview also touches on Mieszkowska's personal engagement with her subjects and their surviving friends and family, the place of cabaret in Polish culture, and comparison of Polish cabaret traditions with those of other countries, ending with an appended list of significant cabaret artists.

More than any other art form, theater performance before the evolution of audio recording and film poses the toughest challenge to the archivist. The intense live action of a classic drama or a satirical cabaret leaves few, always inadequate material traces in playbills, reviews, drawings or restaged photographs, eyewitness accounts, and the usually unreliable memoirs of the players accustomed to embellishing on rather than documenting their achievements. As I first learned while working at the New York Public Library's impressive Billy Rose Theatre Division, these traces consist largely of crumbling newspaper clippings that libraries cannot afford to preserve with the care that they give original manuscripts. A 
researcher literally destroys the evidence even as she is studying it. Nor can any archive-whether in a library or a theater museum-maintain a performance's verbal and visual synthesis. Sets never survive except in the occasional sketchbook left by major designers; costumes must be stored where light, insects, and hangers cannot destroy them-that is, in a warehouse many blocks away from the library and accessible only by appointment. If performers and their shows were categorized as popular rather than serious, it is a forgone conclusion that their scripts and costumes were tossed long ago or, at best, recycled. Only the hit songs of a popular show might resurface because publishers of sheet music wanted to make a quick buck by printing them for their fans.

When I began researching interwar Polish-language cabaret, therefore, I harbored no hopes of a good paper trail and was forewarned that there were almost no live recordings of shows. I expected to find short reviews scattered in thencontemporary newspapers and occasional interviews with and updates on cabaret stars in glossy Hollywood-style magazines such as Kino (Film). I was determined to content myself with these spare sources. To my surprise and delight, however, I made the acquaintance of Anna Mieszkowska, an archivist at the Polish Academy of Sciences (Polska Akademia Nauk, hereafter, PAN), and was permitted access to her well-catalogued treasure trove of materials on cabaret artists before and during World War II. These files also covered the lives and works of many cabaret artists in the vast Polish postwar diaspora, thespians whom the Polish People's Republic had denounced as fascists and traitors because they had been connected with Polish troops attached to the British rather than the Soviet army. Throughout the cold war, émigré performers were cut off from the context that had engendered them and the national audience that they deserved.

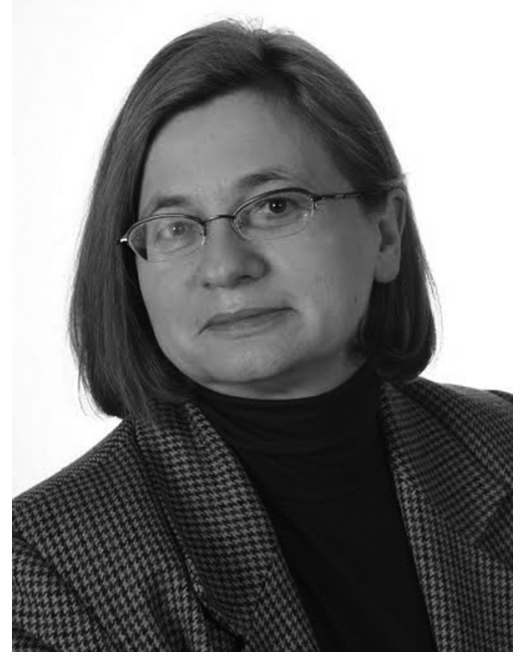

Figure 1. Anna Mieszkowska, archivist at the Polish Academy of Sciences in Warsaw. From the personal collection of Anna Mieszkowska. 
The Polish cabaret archive at PAN makes crucial contributions to the history of Polish theater, popular culture, urban life, and the diaspora. Mieszkowska's quest for materials required extensive travel and exceptional detective skills, for she had to reconnect the fine threads of Polish culture and society across time (interwar and postwar) and space (in-country and abroad). The cabaret merits study as both art form and historical source. As it developed in the interwar period, the Polishlanguage literary cabaret conveyed the latest news through satirical sketches, coined the signature character types of its local society, created first-rate songs that telegraphed a period- and place-specific sensibility, and reinforced the close relationship between performer and patron. The multitalented stars it cultivated often figured as national, regional, or (eventually) diasporic celebrities. Given the cabaret's reflection of its here and now, Mieszkowska's assiduous detection, collection, and repatriation of prewar and émigré cabaret materials over the past three decades comprises an enormously significant project: mapping the local history, tastes, and worldviews of Polish citizens across the globe.

Mieszkowska launched her recovery mission in the early 1990s, recognizing that she had no time to waste in contacting aging performers. She traveled to such émigré cultural centers as London, New York, Washington, DC, Chicago, and Los Angeles in order to meet with survivors or their executors and to gather whatever materials they were willing to preserve in a postcommunist homeland. Mieszkowska's greatest acquisition resulted from her contact with Marina Járosy-Kratochwill, the daughter of the famed cabaret director and conferencier (master of ceremonies), Fryderyk Járosy. Marina knew little of her Hungarian father's importance to Polish cabaret because she had grown up with her mother in Vienna. But she adored her father and managed to preserve all the programs and clippings that Járosy regularly mailed to the family. Mieszkowska flew to Vienna to meet with Marina, invited her to visit Poland and meet with the one survivor who had known her father well, and convinced her to donate Járosy's private archive to PAN. ${ }^{1}$

For the researcher, the materials that Mieszkowska has collected and organized for PAN provide a well-contextualized, unusually integrated resource. The files on specific cabaret writers, directors, and performers include the usual reviews as well as rare programs of shows and posthumous commemorations, correspondence, manuscripts, hard-to-obtain books of sketches and song histories, and both family and professional

1. Fryderyk Járosy (1889-1960), an actor, conferencier, director, and writer, settled in Warsaw in 1924 while touring with the Russian émigré troupe Sinniaia ptichka (The bluebird). Of Hungarian background, Járosy chose to make Poland his homeland. In Warsaw he, Marian Hemar, and the poet Julian Tuwim became known as the "Three Musketeers," who wrote, directed, and helped produce the major Polish-language literary cabarets of the interwar period, following in the footsteps of the long-lived Qui pro Quo. Járosy spent World War II in Warsaw, working for the Polish resistance while in hiding. He put together several touring troupes immediately after the war, and resettled in London, where he very occasionally worked for Radio Free Europe. 


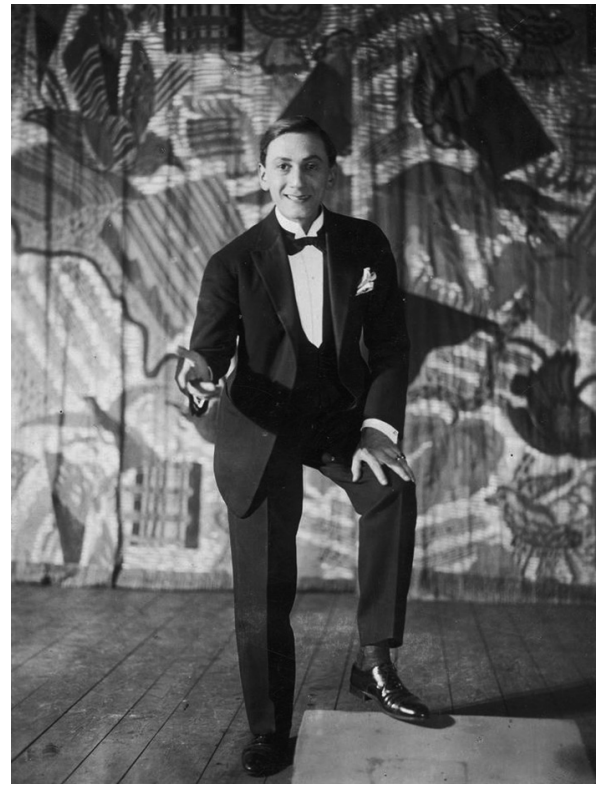

Figure 2. Fryderyk Járosy, the great interwar cabaret director and conferencier. From Narodowe Archiwum Cyfrowe in Warsaw.

photographs. Mieszkowska has processed each file much as a theater historian would, with an eye to ensuring as much biographical coherence as possible. She functions as an invaluable, generous guide to the collection due to her precise knowledge of what was received from whom and her fervent wish to share the history of these artists with the public.

Familiarizing the public with the biographies and performances of Polish cabaret folk has proved more difficult than gathering their ephemeral materials. First and foremost, Mieszkowska and her colleagues at the PAN archives want researchers to know that this rich collection is available. It is perhaps most important that young Poles, both in-country and in the diaspora, come to know and appreciate their bifurcated cultural heritage. Some interest is stirring in Poland, as is evident from the Facebook page Café Bodo II (named after the popular interwar performer Eugeniusz Bodo) and Monika Zakrzewska’s blog, "Co się dziwisz" (Is it any wonder?), which focuses on Polish interwar cabaret and film. ${ }^{2}$ In the meantime, Mieszkowska has tried to spread the word through her own publications, offering an important alternative to popular histories of interwar culture, which sell on the basis of the scandals they promise to dish even as they disseminate false information. ${ }^{3}$ Mieszkowska's first book, Artyści emigracyjnej

2. Café Bodo, www.facebook.com/cafebodo.gj; Co się dziwisz?, http://cosiedziwisz. blogspot.com, both accessed May 7, 2014.

3. See, for example, such works as Stanisław Koper's Życie prywatne elit artystycznych Drugiej Rzeczypospolitej (Warsaw: Bellona, 2011). 
Melpomeny (Artists of Melpomene in emigration) (1998), introduces Polish readers to an extensive group of émigré stars. She devoted her two subsequent monographs to titans of the interwar cabaret-the great writer and later émigré director Marian Hemar (1901-1972) and the aforementioned Fryderyk Járosy. ${ }^{4}$ Mieszkowska's favorite book, Była sobie piosenka: gwiazdy kabaretu i emigracyjnej Melpomeny (There once was a song: Stars of the cabaret and Melpomene in emigration), links the Polish cabaret artists whose paths variously intersected across national borders and cold war divisions in the prewar, wartime, and postwar periods. ${ }^{5}$ There Once Was a Song models the sort of integrated, accurate, accessible cultural history that Mieszkowska hopes other scholars will be interested in writing.

To date, the PAN cabaret collection made its biggest public splash with a major exhibition at Warsaw's Great Theater, on view from April 10 to June 30, 2000. Titled "Fryderyk Járosy-Zawsze Ten Sam" (Fryderyk Járosy_-Always the Same), it drew extensively from the director's recently acquired archive as well as other institutional and private contributions. ${ }^{6}$ Mieszkowska curated the exhibit together with Andrzej Kruczyński, the director of the Museum attached to the Great Theater. Izabela Chełkowska designed the exhibit's enormous, multipart "stage," which led patrons physically through different scenes in Járosy's life-his family home in fin-de-siècle Vienna; the office of the Russian émigré troupe, Bluebird, with which he toured in the early 1920s; a Warsaw café and theater dressing room depicting his interwar years with the cabaret; a movie theater in which the two films featuring Járosy were repeatedly screened (Co mąż robi w nocy [What my husband does nights, 1934], Papa się żeni [Papa is getting married, 1936]); the concentration camp at Buchenwald, where the artist was interned during the last year of the war; and his final home in London. ${ }^{7}$ Life-size cardboard cutouts of Járosy and other cabaret artists "mingled" with their live audience, and photographs and caricatures adorned the walls. The thousands who attended the premiere were entertained by actors who performed hit songs that were debuted in Járosy's cabarets. Visitors glimpsed the guests of

4. Marian Hemar (Jan Marian Hescheles), a lyricist, satirist, playwright, and poet, played a seminal role in writing for Polish-language literary cabarets between the wars. Hemar produced hundreds of songs and sketches in this period. During World War II he was attached as a cultural organizer to the Independent Carpathian Rifle Brigade in Mandate Palestine until he was relocated to London. After the war, Hemar directed a cabaret for London's Polonia and broadcast a show called "Hemar's Theater" on Radio Free Europe. Mieszkowska's biography of Hemar is titled Ja, kabareciarz: Marian Hemar od Lwowa do Londynu [I am a cabaret man: Marian Hemar from Lwów to London] (Warsaw: Wydawnictwo Literackie MUZA, 2006) . Járosy’s biography is Jestem Járosy! Zawsze ten sam [I'm Járosy! Always the same] (Warsaw: Wydawnictwo Literackie MUZA, 2008).

5. Była sobie piosenka: gwiazdy kabaretu i emigracyjnej Melpomeny (Warsaw: Wydawnictwo Literackie MUZA, 2006).

6. Dziennik Polski (London), May 5, 2000.

7. These two films were romantic comedies directed by Michał Waszyński. 


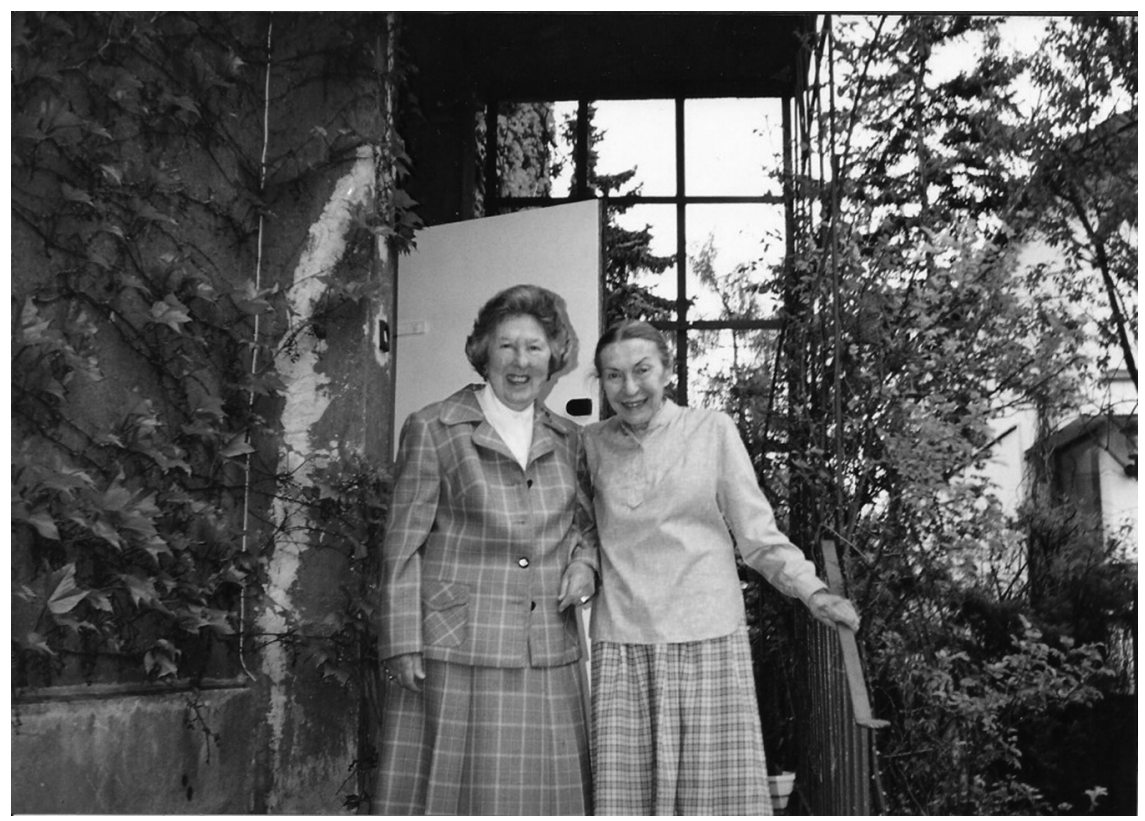

Figure 3. Marina Járosy-Kratochwill, daughter of Fryderyk Járosy, and Stefania Grodzieńska, satirist and cabaret artist. From the personal collection of Anna Mieszkowska.

honor, Marina Járosy-Kratochwill and Stefania Grodzieńska, a satirist and actress who had been a close friend of Járosy's during the war.

The exhibit also attracted star visitors. The day after the premiere, Życie Warsza$w y$ reported sightings of the actor Zbigniew Zapasiewicz (1934-2009), the director Stanisław Tym (1937-), and the singer Irena Santor (1934-), who declared that her "heart" had led her there: "I grew up on the art of interwar performers. They are the ones who inspired me in my career."

My print spotlight on Mieszkowska's work and the cabaret archive at PAN cannot compete with the glamor of this extraordinary exhibit in 2000. But I write this article with the same goal in mind, to make scholars and students aware of the collection's existence and to encourage their use of its exceptional materials. The following interview and list of cabaret artists serve as a further introduction-first, to the story of the collection's genesis and early reception as told by its archivist and, second, to a short list of the artists whose lives and works are featured in the collection. For more information about the collection's contents and use, I invite readers to contact me at beth.holmgren@duke.edu or to contact Anna Mieszkowska directly at annamieszko@op.pl.

8. Ewa Solińska, “Kochał i był kochany," Życie Warszawy, April 11, 2000. 


\section{Interview With AnNa MieszKowskA ${ }^{9}$}

\section{How did you get interested in interwar and émigré cabaret? What or who led you to this topic?}

It all began in October 1982, when Poland was under martial law. I was a student in theater studies at the National Theater School (Państwowa Wyższa Szkoła Teatralna). The head of our unit had organized a scholarly conference to commemorate the fiftieth anniversary of the State Institute for Theater Arts (Państwowy Instytut Sztuki Teatralnej [PIST]), which was founded in 1932 and closed after the German invasion in 1939. Prewar alumni from the acting department had gathered for the anniversary. At that time, many of them were still alive. (Today only one remains with us-the one hundred-year-old Danuta Szaflarska.) They had come from all parts of Poland.

And one person came from London-Irena Brzezińska. I knew nothing about her. But I noticed her since she was sitting in front of me, and her rather elegant attire (especially for an older woman) singled her out. She was wearing black leather pants and a snow-white turtleneck sweater. No one dressed like that in 1980s Poland! During a coffee break, I sat down beside her and started a conversation with her on the pretext that I was planning to write my master's thesis on the diploma performances of PIST alumni.

Irena proved to be a very accessible, warm, and cordial person. We exchanged addresses and phone numbers. She said that she would be returning in a few days to London, where she had been living since 1945 . This news came as a shock to me. We managed to meet twice before she left. Irena first revealed to me the unknown [history] of Polish theater in emigration. During my studies, not a single lecture had been devoted to this topic. More generally, there was no discussion of the cabaret. We had studied theater in the ancient world, during the Middle Ages, the Enlightenment, the Romantic era, and the twentieth century-up to 1939 and after World War II. There had been lectures on the avant-garde theater and the history of the opera and the ballet. But cabaret? In Poland or overseas? Not in our theater history program.

Besides, our professors did not talk about Polish emigration for political reasons. One needed to put in a request, with the rector's signature, to be allowed to read books or periodicals that were published outside Poland or available only in select libraries. I had been able to use the reading room at the Writers' Union once or twice with this kind of permission. But that was all. After a few years, Irena Brzezińska decided to sell her home in London and return to Poland. I was in constant contact

9. The following interview with Mieszkowska, conducted via email in late February 2014, sheds light on her decades of experience as an archivist in Poland and overseas and shares her reflections about the challenges and significance of her work. I am deeply grateful for the effort and time she devoted to answering my questions. I added the footnotes for further information about the individuals she highlights. 


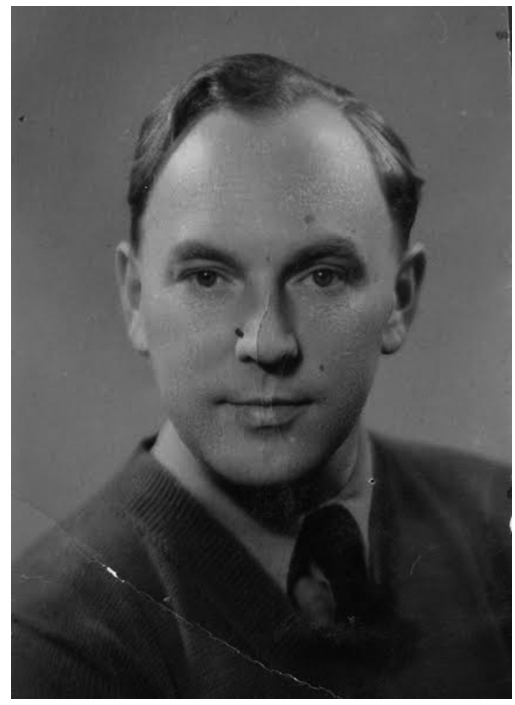

Figure 4. Wiesław Mirecki, stage actor. From the personal collection of Anna Mieszkowska.

with her until her death in 1994. She had given me several important addresses in London and Paris.

The other key person I met in 1982 was a retired actor from the National Theater-Wiesław Mirecki. What a charming older man he was, a real gentleman! He had graduated from PIST in 1935. He performed at the National Theater before the war and fought during the 1939 invasion, after which he ended up in the POW [prisoner of war] camp at Murnau. Since this camp was designated for officers, it included a great many writers, actors, directors, and screenwriters. Naturally, they created a camp theater, about which a very good history has been written. I was interested in what Wiesław told me about his experiences after 1945. Once his camp was liberated, he traveled with a group of actors to Recanati, Italy, where the Drama Theater of the Polish Second Corps was stationed. General Władysław Anders headed up this Polish army, oversaw its evacuation from Russia in 1942, and then led it through Iran, Iraq, Palestine, and Egypt to Italy, where his soldiers fought their first successful battle of the war. The legendary song "Czerwone Maki na Monte Cassino" (The red poppies on Monte Cassino; words by Feliks Konarski, music by Alfred Schütz) was written over the course of that battle in May 1944.

Mirecki reached London with the theater attached to the Anders army in September 1946. There he lived and worked as a manual laborer in restaurants and pubs, at the same time performing in the Polish theater and editing his own little theater journal. He subsisted in these difficult circumstances until the beginning of 1958 , when he returned to Poland. In the 1980 os he showed me programs, photographs, and reviews of his émigré premieres. I drank all this in. Mirecki gave me more surnames and contacts. I could not even dream of traveling to London in 1982. Then my daughter was born in 1984. 
It was only in 1991 that I was able to make the trip. I obtained a passport, a visa for England, and a stipend (just \$50o!) from Jerzy Giedroyc, who very much liked my plan to gather materials about the émigré theaters. ${ }^{10} \mathrm{I}$ had been corresponding with Giedroyc since 1990. When he awarded me the stipend (from the so-called Fund to Support Independent Polish Literature and Culture), he asked that I not advertise that fact in London since he was not much liked there. At that point, I had no idea about political divisions among the émigrés. Giedroyc also gave me more contacts and some advice, which played an enormous role in my subsequent collecting. Our correspondence, which lasted from 1981 to 1991, provided me with the foundation for all that came to pass.

When you began your research, how did people react to your topic? Were they dismissive? Would you say that Polish scholars generally underestimate popular culture-especially popular culture of the past?

I first went to London in September 1991, for two weeks. I had already planned which people to visit and what to see. I confess that I did not see the real London at all! I was interested only in "Polish London" - the Polish Library, the Sikorski Museum, Ognisko Polskie (the Polish Hearth Club founded during the war), the editorial offices for the oldest Polish newspapers (The Polish Daily and the Polish Soldier as well as Polish Week), Dom Lotnika (The house of the airman), which no longer exists, Polish homes for the aged, Polish churches, and the graves of Polish artists in London cemeteries.

I started writing to the émigré newspapers immediately after I returned to Poland. This was the second phase of my research.

The third phase involved direct contact with actors or those who knew them well. It was then that I faced my first disappointment. In most cases, the people I met approached me with reluctance and suspicion. As it turned out, they acted this way because they greatly resented the fact that no one from Poland had been interested in them earlier. I had come to them when most of the great and important artists were already gone. And they wanted to know just what I wanted to write about them, given the fact that Poland had shown no interest in what was going on in Polish theater beyond its borders, where conditions were so tough and they had no support from the government or private sponsors. I became the "whipping boy" for the decades-long separation of national culture from émigré culture.

I brought home very little from this first trip. I was crushed and had no desire to continue the project. I described my disappointments and feelings in a letter to Giedroyc. He sent me this reply: "Please don't be discouraged. Write an open letter to the editors of The Polish Daily about what you're looking for." I did just that, and I included my address. After several weeks, I received so many letters and packages

10. Jerzy Giedroyc (1906-2000) was the founder and editor of the leading Polish émigré literary-political journal, Kultura, published by Maisons-Lafitte, France. 
with programs, playbills, and photos. I began to sort these materials into an album, Artyści emigracyjnej Melpomeny, 1939-1995 (The artists of Melpomene in emigration, 1939-1995), which was published by the London Polish Culture Fund. I could not find a publisher for it in Poland.

There were two openings for the book, both tempestuous! An unbelievable crowd of guests showed up at the Warsaw opening, held in the prestigious space of Dom Literatury (House of literature). Journalists, actors, the media. I had asked a theater historian, someone with whom I was friendly, to say a few words about the book-and he sharply criticized it. I hadn't been prepared for that. His wife later apologized for him; she had been shocked by his reaction. The circle of Polish theater historians gave my book a very cold reception. They accused me of acting like a self-styled "creator of stars and theatrical happenings" outside Poland. In the opinions of these recognized scholars, real theater could exist only in Poland! The most important postwar premieres and film adaptations took place here; the best actors, directors, and screenwriters worked here. Their response was hurtful.

But I understood that I had managed to crack open a rock-hard sanctimony, a collective conspiracy of silence. For fifty years, no one had written or spoken about these people in Poland. My publication showed that Polish theater was not restricted to premieres in Warsaw, Kraków, Poznań, Łódź, or Szczecin. Small theaters in Polish clubs, churches, and Polonia centers were spread all over the world. These theaters sprouted up wherever Poles lived-in the United States, Canada, Australia, and even New Zealand.

In London, the book was received with gratitude but also resentment-that there was too much written about this or that actress and too little about another. That this person was no great director, but another person was. Normal human resentments, which also left me feeling helpless and isolated. There were a great many reviews of the book, most of them positive. It performed its role. I was satisfied that I had preserved something, and I decided to move forward. New projects emerged from my past passion for collecting "wastepaper": biographies of Marian Hemar and Fryderyk Járosy and the book that has given me the greatest joy-Byta sobie piosenka: gwiazdy kabaretu i emigracyjnej Melpomeny (There once was a song: Stars of the cabaret and Melpomene in emigration).

\section{How did Polish popular cabaret and revue music compare with what was being produced in other countries, particularly in Europe? Did composers and lyricists "borrow" from each other?}

In order to answer that question, I need to explain the social mechanisms for reproducing popular music in the 1920s, 1930s, and 1940s. At this point, radio was a novelty in Poland; not everyone had expensive radio sets. Phonographs were also expensive. But dancing was very popular-not only in ritzy locales but also in private homes. People played music to dance to. Lots of songs had instrumental versions, and the vocalists sang only the refrain-that's why they came to be called refrainists" (refrenista). 
Where could people get the sheet music? For this, an enormous music industry was in place. After the premiere of a cabaret show, when the public was leaving the theater and humming, for example, "Nie będziesz Ty, to będzie inna" (It won't be you, it will be someone else) or "Kiedy znów zakwitną białe bzy" (When the white lilacs bloom again), they knew that they would be able to buy copies of the sheet music in a few days (often without the words). Moreover, so-called lyricists and cabaretists bought sheet music from music warehouses located the world over. Marian Hemar admitted (and he was no exception) that he listened to nightly musical broadcasts from London, Paris, and Vienna, and they inspired his compositions. You will see that there are many songs with different titles, but the melodies are the same or very similar to each other.

You must be a talented detective to have been so successful at collecting archival materials. A great many documents and facts about the interwar and émigré cabaret have been discovered and made public thanks to your efforts. How did you track down these documents and, more important, the people who kept them?

I found people through a human chain of goodwill. People whom I met supplied me with the next set of contacts and addresses. This was a matter of intuition and good luck. I discovered Fryderyk Járosy's daughter by attending a garden party in London on my first visit; I kept asking the artists gathered there what they knew about him. One lady in this group went home and found the surname Járosy in an old phonebook. It turned out that the brother-in-law of the famous conferencier was still living in London. He gave me the contact information for Járosy's daughter in Vienna. The brother-in-law died of a heart attack two weeks later. If I had not stumbled on this information in time, I never would have been able to write my biography of Járosy. I have experienced many such coincidences and happy accidents.

\section{Did you discover the same "human chain of goodwill" when you continued your research in the United States in 1995? Did you make any surprising discoveries during your visit here?}

For several years, I corresponded with Tadeusz Wittlin, a writer and satirist, and the man who wrote the words for "Ostatni posłaniec" (The last messenger), an important song in the history of the Polish cabaret; the legendary Ludwik Sempoliński performed it to great effect. Tadeusz's wife, Gena Galewska, joined in our conversation about the cabaret. Before 1939, she had designed costumes for the cabaret stars. Her father, Józef Galewski, was the set designer for many Warsaw cabarets and theaters, starting with Qui pro Quo.

I knew that when Wittlin was writing Pieśniarka Warszawy: Hanka Ordonówna $i$ jej świat (The songstress of Warsaw: Hanka Ordonówna and her world) in the 1970s, he had been in contact with the artist's husband, who lived in Munich and was an editor at Radio Free Europe. Count Michał Tyszkiewicz gave Tadeusz some 


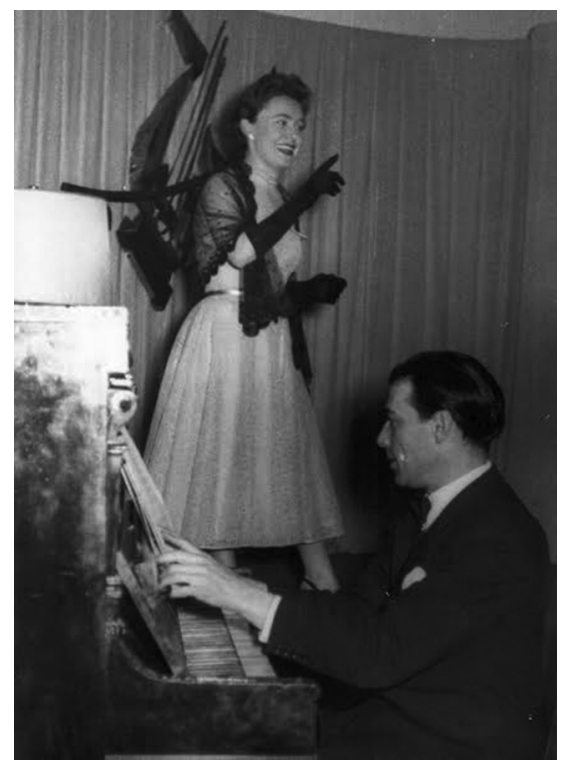

Figure 5. Kaya Mirecka-Ploss, cabaret artist and memoirist, with Wiesław Mirecki. From the personal collection of Anna Mieszkowska.

of the important mementos that he had kept of his wife. ${ }^{11}$ Tadeusz promised to give them to me, but on condition that I travel to Washington, DC, to pick them up personally. This became possible in the autumn of 1995 thanks to a stipend from the Andrzej Jarecki Fund, support that I received from Kaya Mirecka-Ploss, the executive director of the American Center of Polish Culture in Washington, DC.

Over the course of my American trip, I went to New York to visit Nina Polan, who had been an actress in London's Polish émigré theater during the 1950s. (Her actual name was Janina Katelbach, and she died February 16, 2014.) I made a special trip to Los Angeles to collect materials connected with the Air Force's theater unit, which had performed in England and Scotland from 1941 to 1946. In Los Angeles, I visited the grave of the cabaret writer and actor Konrad Tom, who died August 9, 1957. ${ }^{12}$

11. Hanka Ordonówna (1899? 1902?-1950) [Maria Anna Pietruszyńska], the most popular cabaret star between the wars, was a singer, dancer, actress, and occasionally a lyricist and an impresario. She spent the first part of the war in a labor camp in the Soviet Union and, after the Soviet amnesty of the Poles in 1941, she performed in the Soviet Union and other points of exile for Polish troops and civilians-India, Iran, Mandate Palestine. In many cases she accompanied her husband, Count Michał Tyszkiewicz, who was working for the Polish government-in-exile. After the war Ordonówna settled with her husband in Beirut.

12. Konrad Tom (1887-1957) [Konrad Runowiecki] was a cabaret writer, screenwriter, singer, cabaret and film actor, and occasional film director between the wars and during World War II. He was attached to Anders Army as a writer and entertainer; he also worked with Michał Waszyński on several films made under the Army's auspices. After the war Tom emigrated first to London and then to the United States. 
I stayed in the home of the people who had taken care of Tom when he was dying of bone cancer. In Chicago, I visited the home of Feliks Konarski, the popular director of one of the cabaret units attached to the Anders Army, and I rode in a car that sported his pseudonym, "Ref-Ren" (Refrain), on its license plates. ${ }^{13}$ I also made the acquaintance of Robert Lewandowski, who fought in the Warsaw Uprising and, for many years, broadcast radio and television shows promoting Polish culture in the United States.

This proved to be a long, important journey for me. I described it all in a series of reports published in the London Tygodnik Polski (Polish weekly) and my own books about the cabaret. I felt that I had done my duty. I had paid off my debt of gratitude to the people who had entrusted me with their memorabilia and archival documents. I had rescued something, some small fragment of Polish theatrical life outside Poland.

You are researching perhaps the most ephemeral works of art-cabaret and revue shows, which have not been recorded or filmed, and left behind, at best, a meager paper trail. Can these shows be reconstructed?

It is impossible to reconstruct a prewar revue or cabaret show. No one documented these shows. Why? Because they were performed in small, private theaters that operated on a "here today, there tomorrow" basis, without any backing. If the songs in these shows became hits and were recorded or printed, then they were preserved. But many others were lost. During the war, 8 o percent of Warsaw was destroyed. Theater buildings were lost, as were private homes. A great many scores were preserved because someone carried them out of Poland in 1939. For example, we discovered a huge collection of Polish records in a garage in New York in the 1990s; someone had ordered them in 1939. The records had arrived in America but were never unpacked. Now they are back in Poland because someone had decided to tear down the garage, found the records, and got in contact with someone who paid for shipping them back to Poland. If that had not happened, the records would have been destroyed.

I know that this is a difficult question, but it is too important not to ask. What would you advise someone in the United States who has a private collection of materials documenting Polish émigré culture to do? Would it be best to entrust these collections to Polish institutions? Where should these valuable materials be archived?

I would advise anyone who possesses interesting private collections to think about how they would preserve them in perpetuity. I know that I have saved a lot

13. Feliks Konarski (1907-1991) was a lyricist, poet, actor, and writer who first made his name in Lwów cabaret in the latter half of the 1930s. During the war he directed one of the cabaret-revue units attached to the Anders Army and became a great favorite with the Polish troops. Konarski and Alfred Schütz wrote the legendary song, "Red Poppies on Monte Cassino," even as that battle raged in May 1944. After the war Konarski worked with Hemar on cabaret productions in London and then moved to the United States, where he regularly toured Polonia and maintained a radio program. 
of materials, but many more were destroyed by their heirs. Families do not always know the value of the papers that their loved ones collected. And these "papers" are treated like trash and simply thrown out. In Israel, I obtained several valuable imprints mixed in with trash, in stalls peddling junk. Such stalls are everywhere. I have seen them in Paris, Berlin, and Munich. I have used all the materials I have managed to find in a great many publications, the exhibit "Artists of Melpomene in Emigration," and radio broadcasts. Many of these materials are duplicated. I have divided the collections into two parts, donating one to the Archive of the Emigration at the University of Torun and the other to the Archive of the Polish Academy of Sciences in Warsaw, where I work.

\section{What do Poles know today about Polish culture during the war and the postwar emigration?}

Looking back over the past thirty years, I would say that Poles know more about Polish émigré culture than they did when I first heard the names of these émigré artists. They would know more if the articles and books on this topic did not have such small print runs and were not so hard to obtain. The media is interested mainly in what is going on right now, in current scandals.

In the United States, we often refer to the "great American songbook" of classic popular songs. Famous artists regularly perform them, paying tribute to their composers and lyricists. Does such a tradition exist in Poland? Do Poles consider certain prewar songs "popular classics"?

Does this tradition exist in Poland? Of course! Not on a mass scale, but it exists. On Radio Retro, fans of old popular songs meet with the public. The Mieczysław Fogg Song Festival has been in existence for ten years and attracts young artists, often amateurs, to compete. Recordings of old hits are produced. People always love good old songs.

But what constitutes a "good song"? According to Marian Hemar, a good song is one that nonmusical people with bad memories keep on singing, because it has penetrated their ears, hearts, and minds and won't let them go. There are certain songs I love that I hum when I have a bad day- "Może kiedyś innym razem" (Maybe some other time), "Za dawno, za dobrze się znamy" (We've known each other too long and too well), "Zawołaj mnie" (The man I love), "Kiedy będziesz kochany" (When you are loved), etc. ${ }^{14}$ I could go on and on.

\section{Why are these artists important for Poles today?}

We are richer as a people thanks to Polish culture (broadly defined) in emigration. For over fifty years, our culture was divided against our will. I repeat this constantly: at home and in emigration, we sang different songs, read different books, and

14. Mieszkowska notes that Hemar wrote the lyrics of "Zawołaj mnie" to the melody of George and Ira Gershwin's song, "The Man I Love." 
went to different shows. Two different worlds of the imagination existed within the compass of one language. This only changed on June 4, 1989, when the communist government was overturned officially in Poland. In August 1995, I was in London at the last Congress of Polish Culture Abroad. It was a very emotional event for both émigrés and guests from Poland. In the large hall of the Polish Sociocultural Center (POSK) we stood holding hands and weeping — the old émigrés who had reached London between 1939 and 1946 from the displaced person camps or with the Polish Army after dramatic ordeals in different European countries, and those of us joining them from a now-free Poland, after years of hated communist rule. When we talked privately with one another, we mourned the fact that so many important and interesting artists had not lived to see this day.

\section{Are there any specific artists you would like to introduce to American scholars?}

I would like to list just a few of the artists who have been important to me. They left us such valuable materials-photographs, sheet music, reviews, letters, recordings, and memoirs. (Text in italics added by $\mathrm{BH}$.)

Lucyna Aston, the wife of the great singer Adam Aston, was a charming lady. We parted in tears. She was very ill, and I knew that this would be our last meeting. She was incredibly grateful that I had found her, and she could reminisce about her husband!

Adam Aston [Adolf Loewinsohn] (1902-1993) was a renowned singer, actor, and pianist. He performed extensively in Warsaw cabarets and revues, played in several prewar films, and recorded hundreds of songs in Polish, Yiddish, and Hebrew. He was attached to the Anders Army during World War II, after which he and his wife emigrated first to South Africa and then to England.

Renata Bogdańska-Anders, the wife of General Władysław Anders, was a wonderful performer!

Renata Bogdańska-Anders [Irena Renata Jarosewycz] (1917-2010) became a star singer during World War II, particularly after she was attached to the Anders Army and its cabaret-revue units. A performer of beauty and charm, she appeared in several films made in Italy immediately after the war and later performed on concert tours in England, France, and Israel. She married General Anders in 1948 and had their daughter Anna Maria in 1950.

Gwidon Borucki, Renata Bogdańska’s first husband and an actor in the prewar cabaret Cyrulik Warszawski (The Barber of Warsaw), was the first to sing "Red Poppies on Monte Cassino." He was a charming storyteller and my good friend, with whom I made a date to meet in London in May 1994, literally weaning my two-year-old son to do so.

Gwidon Borucki [Gwidon Alfred Gottlieb] (1912-2009) sang in prewar cabarets in Warsaw and starred as an entertainer attached to the Anders Army. After the war, he emigrated first to England and then to Australia, where he worked as an actor in film and on stage and television. 
Irena Brzezińska, one of my first contacts with the émigré cabaret, was a gold mine of memories.

Irena Brzezińska (1911-1994) debuted as an actress in Wilno in 1939 and spent most of the war in Warsaw, serving as a courier for the resistance and fighting in the Warsaw Uprising. After Brzezinska was liberated from the Oberlangen concentration camp, she joined the Drama Theater Unit of the Anders Army and traveled with it to London. She performed on the émigré stage until 1983.

Jadwiga Czerwińska (1913-1994) was a singer and actress who settled in London after World War II and delivered wonderfully distinctive performances of popular songs by Hemar, Andrzej Włast, Ref-Ren (Feliks Konarski), Ryszard Frank, and others for the London section of Radio Free Europe.

Stefania Górska, whom I met when I was in theater school, came to some student show where her prewar songs were performed: "Nasza jest noc" (The night is ours) and "Czy Pani Marta jest grzechu warta?" (Is Miss Martha worth sinning for?). Górska received a standing ovation. I was friends with her daughter Kasia, who is no longer with us.

Stefania Górska (1907-1986) was a dancer, singer, composer, and cabaret and film actress in interwar Poland. After the war, she performed at Syrena, the Warsaw cabaret that carried on the traditions of the best prewar Polish-language cabaret.

Stefania Grodzieńska-lots of memories from her visit with Járosy’s daughter, Marina Járosy-Kratochwill.

Stefania Grodzieńska (1914-2010) was a dancer, cabaret actress, and satirist in interwar and postwar Poland. She and her husband, Jerzy Jurandot (poet, lyricist, satirist, and impresario), were close friends with Fryderyk Járosy during Warsaw's wartime occupation. Grodzienska and Jurandot helped build the cabaret Syrena in postwar Warsaw. Grodzieńska published an important first biography of Járosy, Urodził go Niebieski Ptak (The bluebird brought him) in 1988.

Lola Kitajewicz-Rand, an actress who performed in The Barber of Warsaw, was a star in "Hemar's Theater" in London after the war.

Helena Kitajewicz-Rand (1915-1993), an actress in interwar cabaret, fled Poland in 1939 through Romania to Palestine, where she performed at a soldiers' theater. Kitajewicz-Rand was the first to sing Hemar's "Marsz Karpackiej Brygady" (March of the Carpathian Brigade) on May 3, 1941. She also performed at the Li-La-Lo Theater in Tel Aviv and, beginning in 1949, at Hemar's cabaret and in Radio Free Europe programs in London.

Włada Majewska, a star of the prewar "Lwów’s Merry Wave," was a wonderful performer of Hemar's Lwów songs in emigration, a delightful madwoman who wanted to throw me down the stairs when I objected to her naming Hemar as the author of "When You Are Loved." We worked together on the album Za dawno, za 


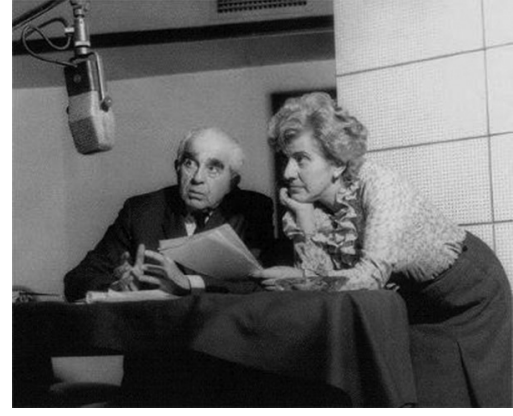

Figure 6. Włada Majewska, journalist, actor, and satirist, with great cabaret writer Marian Hemar when they worked together at Radio Free Europe. From the personal collection of Anna Mieszkowska

dobrze się znamy: Piosenki i skecze Mariana Hemara" "We've known each other too long and too well": Songs and sketches by Marian Hemar), and I knew the author of that song was Bronisław Horowicz, who was still alive at that time in Paris and with whom I was in contact.

Włada Majewska (1911-2011) was a journalist, singer, actor, and satirist, who first achieved fame on the show "Wesoła Lwowska Fala" (Lwów's Merry Wave), which was broadcast weekly on Polish radio. During World War II, she served Polish troops in the United Kingdom and then was attached to the Anders Army when it reached Europe. After the war, Majewska performed in Hemar's cabaret and worked for Radio Free Europe.

Maria Modzelewska, whom I visited in Skolimów (a rest home for veteran Polish actors), left Poland in September 1939 and lived in the United States for fifty years, mainly in New York. When I came in, she was lying in bed and humming "When the white lilacs bloom again." Under her pillow she kept a little book of Hemar's verse. She treated me to cherry vodka. I attended her funeral.

Maria Modzelewska (1903-1997) was a screen and stage actress before the war and occasionally appeared in the cabaret. She was married to Marian Hemar; the two were officially divorced in 1956. In the United States, she was a member of the Circle of Polish Stage Artists.

Jan Nowak-Jeziorański, the director of Radio Free Europe, put me on the track of locating the last radio recording of Fryderyk Járosy in 1960-an interview that was never broadcast.

Jan Nowak-Jeziorański (1914-2005), a journalist, social activist, and politician, served in Poland's Home Army during World War II. After the war, he worked for the BBC and directed the Polish section of Radio Free Europe from 1951 to 1976. He returned to Poland in 2002.

Zofia Sikorska-Ratschka, who was the seamstress for émigré actresses in London, was the wife of actor Roman Ratschek. She was a gold mine of rumors, anecdotes, and memories. 
Alfred Schütz, with whom I corresponded and talked over the phone and from whom I obtained a great deal of important information. Though I could not travel to Munich, I sent journalist friends from Polish Radio to record his memories.

Alfred Schütz (1910-1999) was a composer and musician who first performed on "Lwów's Merry Wave" broadcasts and then moved to Warsaw, where he composed for operettas and cabarets. He was attached to the Anders Army, conducting an orchestra along with Henryk Wars and Henryk Gold and preparing and recording radio broadcasts. Schütz is the composer of "Red Poppies on Monte Cassino." He emigrated to Brazil in 1947 and then to Munich in 1961, where he composed songs to be performed on Radio Free Europe

Zofia Terné was a star whom I never met, but whose memory lives on in London. Zofia Terné [Wiera Chajter] (1909-1987), dubbed "The Warsaw nightingale," was a singer, pianist, actress, and composer who starred in several interwar Polish-language literary cabarets. During World War II, she was attached to the Anders Army, where her performances earned her the nickname "The Little Corporal." After the war, she performed in various London theaters and cabarets for Polonia and worked with the $B B C$ and Radio Free Europe.

Wojciech Wojtecki, a beloved performer of Marian Hemar's, had been an actor in the Polish Theater and the National Theater. He had a marvelous voice; you fell in love with him when he sang, "Pani się nic nie zmieniła" (Madame, you haven't changed a bit).

Wojciech Wojtecki (1908-1964) was an actor and theater director on the prewar stage and directed the Soldiers' Theater of the Independent Carpathian Rifle Brigade. After the war, he directed the Actor's Theater in London and was president of the émigré Union of Polish Stage Artists from 1957 to 1960. 